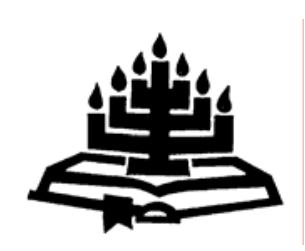

\title{
A theological assessment and interpretation of the Johannine Paraclete- Spirit
}

Johann Joubert

Research Unit for the Study of the New Testament

University of Pretoria

PRETORIA

E-mail: jvdjoub1@aapt.net.au

\begin{abstract}
A theological assessment and interpretation of the Johannine Paraclete-Spirit

The Johannine portrayal of the Paraclete-Spirit gives us a fuller understanding of the identity, role and function of the Holy Spirit. The Paraclete-Spirit in the Johannine Gospel works to glorify Jesus, and make the Father known. Because of the presence of the Paraclete-Spirit Jesus becomes omnipresent, is in his followers and is permanently with them. Through the ParacleteSpirit believers are again united with Jesus as Jesus is united with the Father. Because of the presence of the Paraclete-Spirit Jesus' followers become participants in his life and work through faith in Him.
\end{abstract}

\section{Opsomming}

'n Teologiese evaluasie en interpretasie van die Johannese Parakleet-Gees

Die Johannese weergawe van die Parakleet-Gees bied 'n vollediger begrip van die identiteit, rol en funksie van die Heilige Gees. Die Parakleet-Gees in die Johannese Evangelie werk aktief daaraan mee om Jesus te verheerlik en die Vader bekend te maak. Vanweë die teenwoordigheid van die ParakleetGees word Jesus ook alomteenwoordig, is Hy in sy volgelinge en is Hy permanent by hulle. Deur die Parakleet-Gees is gelowiges weer met Jesus verenig net soos Jesus met die Vader verenig is. Vanweë die teenwoordigheid van die Parakleet-Gees word die volgelinge van Jesus deelgenote aan sy lewe en werk deur hulle geloof in Jesus. 


\section{Introduction}

It is clear in my mind that although we could not "discover" one specific figure in the socio-cultural environment of the first century Mediterranean world, the Johannine Paraclete-Spirit figure fulfilled a very unique and specific function in the ancient world as portrayed in the Johannine narrative. Given the information gathered in my research we can say that in the Johannine milieu the Paraclete-Spirit functioned as a teacher, a guide and instructor, an advocate and a witness, an agent of renewal and a companion.

Maybe one of the greatest deficiencies of some of the earlier studies of this topic is the fact that scholars tried to lock these functions into one socio-cultural setting and tried to explain the whole concept from that vantage point.

We should take a leaf out of the book of Parsenios (2005) regarding the way he approached the Johannine farewell discourses. He indicates that in the past scholars have usually interpreted the fourth Gospel either as functioning within a Greek socio-cultural setting or within a Judaist socio-cultural setting. He contends that this is wrong. He plays with the concept of the one and the many. It should not be an either or, but a both and more. Secondly, he also indicates that it would not be right to see the genre of the farewell discourse as that of a testament or an ancient drama of tragedy. We should see it as both and more. The farewell discourses are not merely one more example of the Biblical testament. They also resonate with the Greek tragedy, ancient consolation literature and the literary symposium. He thirdly also suggested that we should see the farewell discourses as more unified and yet also more diverse. It is more unified in the sense that the many discourses actually form one narrative unit. It is more diverse, since this one narrative unit makes use of multiple genres simultaneously.

\section{The identity of the paraclete-spirit}

What does this have to do with the paraclete-spirit? It is my contention that the Johannine perspective regarding the paraclete-spirit operates in a much similar fashion. We should not seek the identity of the paraclete-spirit in any one specific socio-cultural background or setting. He is neither a Jewish nor a Greek figure, but both and more. He functions in all social-cultural settings. Any one-dimensional assumption regarding the socio-cultural origin of this enigmatic figure would ultimately lead to dissatisfaction. 
Furthermore, we could also state that there is also a surprisingly simple solution regarding the origin of this enigmatic figure. Although he functions in all socio-cultural environments, the Johannine perspective is consistent. The paraclete-spirit is always under discussion in the immediate context of and in comparison with Jesus. Is this not one of the most important snippets of information given regarding the paraclete-spirit?

From our study (Joubert, 2005) we have learned that the Johannine narrative reveals that Jesus' departure from the world will be followed by the appearance of the Paraclete-Spirit. The Johannine Paraclete-Spirit is no more or less an inscrutable, unfathomable and enigmatic figure than the Johannine Jesus. There is no one with whom we can compare Jesus, since He is from above. However, we have someone from above that precedes the Paraclete-Spirit with whom we can compare Him - Jesus Himself. The confusion surrounding the Paraclete-Spirit does not arise from the Johannine narrative itself, but from efforts to define this term accurately. I have shown in chapter two of my research (Joubert, 2005) that this is not possible.

A specific problem presents itself when we try to apply an appropriate meaning to the Greek word that corresponds with the activities allocated to the Johannine Paraclete-Spirit. Problems arise when scholars attempt to place the paraclete-spirit in a specific socio-cultural context. We have established that these two subjects of debate, the title and the background of the figure that carries the title still have not been resolved. We have also adjudged that the Paraclete-Spirit is unmistakably the Holy Spirit and is accordingly identified in John 14:26.

A variety of scholars recognise that what is said of the paracletespirit is not incompatible with what is said throughout the New Testament of the Holy Spirit. ${ }^{1}$ Even so, the relation of the paracletespirit in the parting discourses to the Holy Spirit in the remainder of the Gospel has been a matter of debate.

Nevertheless, for all the difficulty in trying to understand the background of the paraclete-spirit, the actual functions of this figure in the Johannine narrative are relatively straightforward.

1 See for instance Brown (1984:1139-1141), Dietzfelbinger (1997:1-12), Moloney (1998:48), Schnackenburg (1982:138-154), et cetera. 
Even more to this point, the Johannine Paraclete-Spirit is best understood, not in relation to other Biblical figures outside the Johannine Gospel, but in relation to the Johannine Jesus. The close connection between Jesus and the Paraclete-Spirit is a primary concern of this narrative. ${ }^{2}$

\section{The Paraclete-Spirit and Jesus}

The Paraclete-Spirit continues Jesus' work. The Paraclete-Spirit will teach and remind the disciples of all that Jesus said to them (John 14:26), He will testify on behalf of Jesus (John 15:26), and He will proclaim only what is heard from Jesus (John 16:13). As Jesus says, "... He will take what is mine and declare it to you" (John 16:14).

There is still, however, a more profound facet to the connection of Jesus and the Paraclete-Spirit that was revealed. The ParacleteSpirit does not merely succeed Jesus and complete his earthly work; He also somehow "re-presents" Jesus. That the Paraclete-Spirit makes Jesus present is implicit in Jesus' promise that He will send to the disciples a[Ion parakl ht on (John 14:16). The expression stresses that Jesus himself is the ehot parakl ht $0 \sim$. This unspoken association is made clear in a number of statements about the Paraclete-Spirit that we can compare with statements about Jesus.

Exegetical analyses indicate these comparisons. It starts to a certain extent very discreetly. The Paraclete is described as t $0 ; p$ neuma t $h \sim$ a) hqei (John 14:17; 15:26; 16:13), and Jesus is called al hqeia (John 14:6). Jesus is said to be the of a fio t ou ' qeou' (John 6:69), while the Paraclete-Spirit is identified as the p neuma t 0 ; a jion (John 14:26). In a similar way John reminds us that the Paraclete-Spirit e[ qh/(John 15:26; 16:7, 8, 13), just as Jesus el hlvuqa en t w/ojomat $i$ t ou 'patroy (John 5:43). What was said about Jesus is just as true for the Paraclete-Spirit exhl qon para; tou'patro; kai; el hvuqa eij t on kos mon. Both have "come into the world" (John 16:28; 18:37).

Both the Paraclete-Spirit (ekp or euet a i) and Jesus (ejerxoma i) come forth from the Father. The Father edwken the Son (John 3:16), and likewise He dws ei the Paraclete-Spirit when the Son requests it to be done (John 14:16). Similarly, just as the Father a pest eil en the Son (John 3:17), He pemy ei the Paraclete (John 14:26).

$2 \quad$ See e.g. Burge (1987:197), Segovia (1991:94-97), and Tolmie (1995:134-135). 
This is not where this comparison ends. When it comes to interaction with the disciples, the connections become even more explicit. For instance, while the world cannot ginwskei or know the Paraclete-Spirit, the disciples ginws ket e Him (John 14:17), just as they ginws ket e and ewr a kat e Jesus (John 14:7, 9).

Both the Paraclete-Spirit (John 14:17) and Jesus (John 14:20, 23; $15: 4,5 ; 17: 23,26)$ are to monhvwith - and within - the disciples. Where the Paraclete-Spirit will guide (ophghgei) the disciples en $\mathrm{th} /$ a) hqeia/pash/(John 16:13), Jesus is the Way (oflor) and the Truth (a) hqeia) according to John 14:6. The Paraclete-Spirit teaches (didaxei) the disciples (John 14:26-27), just as Jesus teaches (dida s kwn) the people (John 6:59; 7:14, 18).

The Paraclete-Spirit mart urh ei as a Witness (John 15:26), just as Jesus marturw'as a Witness (John 8:14). In addition, the teaching and the testimony of the Paraclete-Spirit are exclusively about Jesus (John $14: 26 ; 16: 12-13$ ). This is functionally equivalent to the way in which all of Jesus' teaching and testimony are about the Father (John 8:28; 7:27-28; 14:13; 17:4).

In the Johannine narrative we find analogous examples of interaction concerning the disciples and the world. The world cannot accept (John 14:17), or see (John 14:17), or know the ParacleteSpirit (John 14:17), just as it cannot accept (John 5:43) or see (John 16: 16) or know (John 16:3) Jesus. Conversely the disciples can accept, see and know both Jesus and the Paraclete-Spirit.

It is evident therefore, from the Johannine narrative perspective that the work of Jesus and the work of the Paraclete-Spirit overlap in a variety of contexts and fashions. Brown (1984:1141) articulates the consequences of this relationship as follows:

Thus, the one whom John calls 'another Paraclete' is another Jesus. Since the Paraclete-Spirit can come only when Jesus departs, the Paraclete-Spirit is the presence of Jesus when Jesus is absent. 3

This function of the Paraclete-Spirit as Jesus' double comes directly form the Johannine narrative. It comes through most clearly in the

3 Windisch (1968:20) might not be that far off the mark when he identified the Paraclete-Spirit as Jesus' "Doppelganger" or double. He states that this comparison with the intercessory function of Jesus in heaven becomes even more evident when it is compared with John 16:26 and 1 John 2:1. 
first Paraclete-Spirit passage in the expression about a[lon parakl ht on (John 14:16-17). However, in this passage, none of the other functions of the Paraclete-Spirit (teaching, guiding, assisting, reminding, testifying, convicting or prosecuting) come into view. We are told, in the words of Schnackenburg (1982:75), that all that is mentioned in John 14:16-17 is that the Paraclete-Spirit is given to the disciples and "his significance for the disciples in the world is emphasized." 4

Jesus promises that a l on parakl ht on will come to the disciples after He Himself has departed. Up to this time, Jesus has fulfilled the role of Paraclete but now another will be sent in his place. This means more than that the Paraclete-Spirit will do what Jesus did in his absence as Brown stated.

It is also important to understand that this is not just a case of action. When Jesus promises that the Paraclete-Spirit will i fla meq' umwn eijton aijnina hX (John 14:16), that expression calls to mind the aphorism documented in Matthew, where Christ promises to his

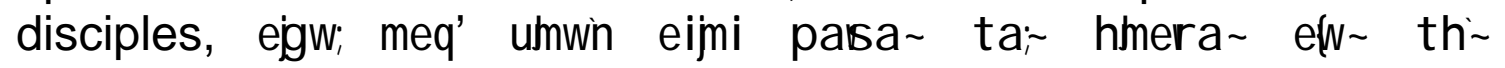
sunt el ei $\sim$ t ou' a ijwno (Matt. 28:20). The important distinction is that what Matthew depicts Christ saying about Himself, the Johannine narrative perspective applies to the Paraclete-Spirit. This highlights the fact that the Johannine message is unequivocally that the Paraclete-Spirit is Christ's agent of eternal presence with his disciples.

Johnston's (1970:86) observation that after Jesus' departure the spirit of truth will come to help the faithful and to represent their Lord, is therefore correct. However, Johnston does not interpret the Holy Spirit as personal, but merely as a power. It seems more appropriate given the consistent comparison between Jesus and the Paraclete-Spirit as indicated earlier, that the personal presence of the Paraclete-Spirit makes up for the absence of Christ. 5 In other words, the Paraclete-Spirit is making Jesus present to the disciples in a different form and manner. Without actually being Jesus, He takes the place of Jesus and makes Jesus present at the same time.

4 Schnackenburg (1982:75) emphasises, however, that this significance is not to be understood in the context of Him being a Comforter for He has above all the task to strengthen the disciples' faith so that they can fulfil their task in the world. Interpreted this way the basic task of the Paraclete-Spirit, as Comforter, is that of equipping for service.

$5 \quad$ See here for instance Keener (2003:962-969). 
For these reasons I have stated earlier that the Paraclete-Spirit fulfils the functions of the earthly Jesus and more.

Parsenios (2005:82-83) asserts that there is a close association between the Paraclete-Spirit saying in John 14:15-17, and the subsequent statements about Jesus' return in John 14:18-21. This connection expands the present discussion. The descriptions of the Paraclete-Spirit's "coming and indwelling" and the "coming back and indwelling of Jesus" are placed in a parallel relationship. ${ }^{6}$ The following tabel demonstrates these connections the best:

\begin{tabular}{|l|l|l|}
\cline { 2 - 3 } \multicolumn{1}{l|}{} & Paraclete & Jesus \\
\cline { 2 - 3 } \multicolumn{1}{l|}{} & John 14:15-17 & $\begin{array}{l}\text { John 14:18- } \\
21\end{array}$ \\
\hline $\begin{array}{l}\text { Necessary to love Jesus, keep his } \\
\text { commands }\end{array}$ & 15 & 21 \\
\hline $\begin{array}{l}\text { Giving of Paraclete; coming back of } \\
\text { Jesus }\end{array}$ & 16 & 18 \\
\hline World will not see Paraclete or Jesus & 17 & 19 \\
\hline $\begin{array}{l}\text { Disciples will recognise Paraclete and } \\
\text { Jesus }\end{array}$ & 17 & 19 \\
\hline $\begin{array}{l}\text { Paraclete and Jesus will dwell in the } \\
\text { disciples }\end{array}$ & 17 & 20 \\
\hline
\end{tabular}

Brown (1982:644) declares:

This kind of parallelism is John's way of telling the reader that the presence of Jesus after his return to the Father is accomplished in and through the Paraclete-Spirit. Not two presences but the same presence is involved.

Parsenios (2005:82) rightly states that with the last phrase of Brown's quotation, a corrective, or at least a caution, can be included in the "harmony of presence" that very clearly exists between Jesus and the Paraclete-Spirit. Following the promise in the first Paraclete passage (John 14:16-17), Jesus promises to come to the disciples (John 14:18). 
What is the significance of this? According to Parsenios (2005:83):

most modern scholars connects these promises to the postresurrection appearances of Jesus. As the resurrected One, Jesus will not leave the disciples as orphans, but will come to them 'in a little while' (John 14:18-19). But, the idea that this will keep the disciples from being orphans is not satisfying. For, if this is the correct reading, then Jesus will once again leave them orphans after his final departure. A more permanent presence is needed, and, for this reason, many people, in ancient and modern scholarship, have argued for some other form of Jesus' coming to the disciples. ${ }^{7}$

In Johannine thought the Paraclete-Spirit has taken on a fuller or more precise character - the character of Jesus. In Johannine thought the personality of Jesus has become the personality of the Paraclete-Spirit. As the Logos of revelation (and Wisdom) has been identified with the earthly Jesus and stamped with the impress of his character (John 1:1-18), so the Spirit of revelation has been brought into conjunction with the heavenly Jesus and bears the stamp of his personality.

Aune (1972:126-135), Beasley-Murray (1999:258), Brown (1984: 1141), De la Potterie (1976:120-140), Keener (2003:966-969), Köstenberger (2004:438-440), Moloney (1998:43-44) and Parsenios (2005:83), are all correct in debating that this permanent presence is reflected in the sending of the Paraclete-Spirit. Justification for this lies above in the various sets of parallels between the consonant activity of Jesus and the Paraclete-Spirit, especially in the close connection between what is promised about the Paraclete-Spirit in John 14:16-17 and what is promised of Jesus in John 14:18-21. Some scholars rightly pointed out that most of the personal functions of the Paraclete-Spirit are found in parallels with Jesus. 8 Keener (2003:965) mentions that the postpentecost believers saw the Paraclete-Spirit as personal, because they experience him as the personal Presence of Jesus or the Mediator of that presence.

Parsenios (2005:83) contends that the sending of the ParacleteSpirit seems to fulfil the promise that Jesus will return. He debates, however, that Brown (1984:1141) might have gone too far in

7 Moloney (1998:43-44) discusses this matter in depth. See also Casurella (1983:43-45, and 143-144), and Dietzfelbinger (1997:44-66).

$8 \quad$ Burge (1987:141) summarises the parallels between Jesus and the Spirit. 
referring to the Paraclete-Spirit as "another Jesus". According to Moloney (1998:44) the Paraclete-Spirit and Jesus can be closely associated only if one recognises that they are also distinct. Even though the disciples can experience Jesus' life-giving presence through the Paraclete-Spirit, Jesus is, in fact, departing from the world (John 14:19).

To the disciples the Paraclete-Spirit will be what Jesus Himself has been to them, yet the Paraclete-Spirit is not Jesus. The coming of the Paraclete-Spirit will be equivalent to a coming of Jesus, and yet the Paraclete-Spirit is not Jesus. This indicates that in Johannine thought there is a unique relation between Jesus and the ParacleteSpirit.

Moloney (1998:43) feels very strongly about the fact that the distinction between the physical Jesus, who is departing, and the "other Paraclete," who will be given (John 14:16), must be maintained. Here we can agree with Johnston (1970:87) who states that the Paraclete-Spirit is "another Jesus" only in the sense that He is Jesus' representative. Yet, He does make Jesus present, inasmuch as He re-presents Jesus (Johnston, 1970:86). This is analogous to what is said in 1 John 3:24: "We know that he (Jesus Christ) abides in us by the Spirit which he has given us."

Parsenios (2005:84) concludes that although the place of the paraclete-spirit in the history of ancient religious thought is hard to pinpoint precisely, the role of the Paraclete-Spirit within the gospel is relatively clear. The findings of the current article affirm this view. The perspective of the Johannine narrative is quite clear: The Paraclete-Spirit represents Jesus, after his departure. Furthermore, what is said regarding the Paraclete-Spirit is modelled on what is said about Jesus, especially in the first Paraclete-Spirit passage (John 14:15-17).

We have seen in the earlier discussions that this is undoubtedly not the only function of the Paraclete-Spirit. What is important, nevertheless, is the fact that the Johannine Gospel itself and the Johannine perspective provide us with the most important critical information to comprehend who the Paraclete-Spirit is. When you consider the literature available, however, it becomes apparent that the most difficult thing about John's Paraclete-Spirit is that the Paraclete-Spirit is resembled loosely to a variety of other figures (prophets, angels, Moses/Joshua typology) but corresponds not to any one of these figures exactly and accurately. 
We find that in Johannine thought the foundation for a distinctive religious experience of believers would be the distinctive features of the Johannine Paraclete-Spirit and his relation to Jesus. The Paraclete-Spirit is the Spirit of Jesus - that is, He continues the work of Jesus. We can put it more strongly in Johannine terms: He continues the presence of Jesus. John brings this out in a variety of ways. It is implied in John 1:32-34 where the Paraclete-Spirit descended on Jesus and remained on Him emeinen ep' a ut on. It seems that according to Johannine thought the "fusion"9 of Jesus and the Paraclete-Spirit was sustained during Jesus' ministry and continued after his departure.10

The pneuma that came from above brings about new life. The Johannine narrative states that the experience of this new life alone does not sufficiently characterise the activity of the Paraclete-Spirit (John 3:5-8; 4:10-14; 6:63; 7:37-39; 20:22).

The importance of this Johannine thought is that it presents an immediate and direct continuity between believers and Jesus. As Dunn (1975:251) states:

The lengthening time gap between John and the historical Jesus, and the continuing delay of the Parousia do not mean a steadily increasing distance between each generation of Christians and the Christ. On the contrary, each generation is as close to Jesus as the last - and the first - because the Paraclete is the immediate link between Jesus and his disciples in every generation. That is to say, the Spirit provided the link

9 Here we should consider the theological concept of perichoresis. Although this is not a Johannine word, the concept is very much Johannine. We see something of this mutual indwelling in John $14: 11,20-21,23 ; 15: 1-11 ; 17: 21,26$; 1 John 2:5b-6, 20, 24-25; 3:9, 24; 4:13-15, and 5:20.

10 Dunn (1975: 350-351) correctly states that it is implied in John 6:62-63 and John $7: 37-39$, where it is clear that the language of eating the flesh of Jesus and drinking the water from Jesus symbolises the believing reception of the lifegiving Spirit. It is implied in the relationship or parallelism between the ministry of Jesus and that of the "Paraclete": for example, both come forth from the Father (John 15:26; 16:27-28), both are given and sent by the Father (John $3: 16-17 ; 14: 16,26$ ), both teach the disciples (John 6:59; 7:14, 28; 8:20; 14:26) and both are unrecognised by the world (John 14:17; 16:3). It is implied in John 19:30 (probably) and John 20:22, where the Spirit is portrayed as the spiritbreath of Jesus. Above all it is indicated in the explicit description of the Spirit as the "other Paraclete" or Counsellor, where Jesus is clearly understood as the first Paraclete (1 John 2:1) and by the fact that the coming of the Spirit obviously fulfils the promise of Jesus to come again and dwell in his disciples (John 14:1526). In short, "the Paraclete is the presence of Jesus when Jesus is absent". 
and continuity not the sacraments or offices or human figures. The vitality of Christian experience does not cease because the historical Jesus has faded into the past and the coming of Jesus has faded into the future; it retains its vitality because the Spirit is at work here and now as the other Paraclete.

\section{Theological significance of the Johannine description of Paraclete as Spirit}

It is a well-known fact that the Greek word pneuma is a neuter gender word.11 It would therefore be fair to assume that any pronoun used to substitute pneuma should normally also be neuter. However, John did not follow this grammatical pattern. Instead, he used masculine pronouns to designate the Paraclete-Spirit.

\begin{tabular}{|c|c|c|}
\hline Text & Noun & Masculine pronoun \\
\hline John 14:16 & Parakl hton (masc.) & a [ I on \\
\hline John 15:26 & pneuma (neuter) & ekeiǹo \\
\hline John 15:26 & pneuma (neuter) & O角 \\
\hline John 16:7 & parakl hto (masc.) & a ut on \\
\hline John 26:8 & parakl ht o (inferred) & ekeiǹo \\
\hline John 16:13 & pneumà (neuter) & ekeiǹo \\
\hline John 16:14 & pneuma (neuter) & ekeiǹo \\
\hline
\end{tabular}

In John 14:17 we have the neuter noun pneuma with the neuter pronoun ô according to the general grammatical rule. However, in the cases mentioned in the table above, the general grammatical rule is not followed. We are suggesting that we should consider that the Johannine author changed the grammatical rule on purpose in the abovementioned cases, to emphasise the personal character of the Paraclete-Spirit.

11 This is one of the main reasons why the Unitarians do not accept that the Holy Spirit as a distinct person separate from the Father and the Son. 
As motivation for this view, we are arguing that there would have been no reason to change from the neuter to the masculine in John $15: 26,16: 13$ and 14 unless the Paraclete-Spirit was understood to be a person. 12 We might therefore interpret this to imply that the Johannine Paraclete-Spirit is in nature similar to the Father as $\mathrm{He}$ is similar to the Son and that this text might be used among others to indicate that $\mathrm{He}$ is the Third Person of the Trinity.

However, it is important to keep in mind that John did not develop a cut-and-dried Trinitarian theology. At most we can say there are glimpses of Trinitarian thought. Such a doctrine can only be addressed from the whole of Scripture and should not be addressed from only one Biblical author. Nevertheless, it is permissible to try and identify the glimpses that the Johannine narrative gives us that infer the deity of the Paraclete-Spirit. The descriptions in the following paragraphs are worth mentioning. ${ }^{13}$

\section{Johannine indications of the deity of the Paraclete- Spirit}

\subsection{The omnipotence of the Paraclete-Spirit}

In John we read that the Paraclete-Spirit is metaphorically compared with the wind that blows where it wishes (John 3:8). We also read that Jesus could minister the way He ministered, performing the miracles that $\mathrm{He}$ performed, because of the Paraclete-Spirit's emeinen ep' a ut on according to John 1:32 and menon ep' a ut on in John 1:33. Jesus promised his disciples that they would do even greater works once the Paraclete-Spirit has come (John 14:12). We could say that John portrays a picture of the Paraclete-Spirit as allpowerful. However, this point could be argued much stronger if you

12 In 1988 I argued the case of the gender of parakl ht $0 \sim-$ that He is male, like the Father and the Son. I believe that the arguments were taking the issue too far (see Joubert, 1988:67). The male pronouns were not used to reveal gender, but merely to indicate personality. But even this should not be taken too far, especially when this is argued from a dogmatic perspective and not an exegetical perspective. Systematic theology should not prescribe to the exegete the way a text is to be interpreted. Exegesis should, however, determine how a systematic theologian systemises doctrinal thought.

13 Chapter three of my study of The idea of God in the thought of Jürgen Moltmann (Joubert, 1997) indicated that there are certain attributes of God that belong distinctly to the Godhead. In Johannine thought, we get some of these distinctive attributes in relation to the Paraclete-Spirit. 
take texts like Luke 1:35, Micah 2:8 and Isaiah 40:28 into consideration as well. 14

\subsection{The omnipresence of the Paraclete-Spirit}

In Psalm 139 David exclaims that he cannot flee from the presence of the Spirit of God.15 If he ascends to heaven, He is there. If he descends into the depths of the earth, the Spirit is there also. Even if he could fly away swiftly, he could not escape the presence of the Spirit. This is an Old Testament perspective of the omnipresence of the Holy Spirit. The omnipresence of the Spirit is also taught in the Johannine Gospel. When Christ taught the disciples that the Spirit would dwell in them all (John 14:17), it is an inference of the Spirit's omnipresence.

\subsection{The eternal character of the Paraclete-Spirit}

In Hebrews 9:14 the Holy Spirit is called the Eternal Spirit. ${ }^{16}$ Through the Eternal Spirit Jesus offered Himself without blemish to God. In Johannine thought the Paraclete-Spirit ina meq umwn' eif t on a i wha $h X(J o h n$ 14:16). We could interpret eif t on a iwna hX to mean, "He will be unto eternity". We can infer from this that the Johannine Paraclete-Spirit is an eternal Being.

\subsection{The holiness of the Paraclete-Spirit}

One important aspect of deity is that God is holy, entirely set apart and separated from sin and sinners. If we take John 14:26 into account, the most common name for the Paraclete-Spirit is Holy Spirit. This indicates that the Spirit also possesses the transcendent attribute of deity.

14 The omnipotence (all powerfulness) of the Holy Spirit in the Old Testament is seen in creation. In Genesis 1:2 the Holy Spirit is seen hovering over creation as a hen over its young. We could say that the Holy Spirit also gave life to creation.

15 See LXX Psalm 138:7 "p ou 'poreuqw'ajp; t ou'pneumat or sou kai; ajp; t ou' pros wp ou s ou pou'f ugw" and BHS Psalm 139:7.

16 There is a problem in the interpretation of this passage in that it is not entirely clear whether pneuma refers to the Holy Spirit or whether it is a reference to the human spirit of Christ. Although either is possible, most scholars argue in favour of the Holy Spirit. 


\subsection{The truthfulness of the Paraclete-Spirit as Spirit of truth}

The Paraclete-Spirit is named the t 0; p neuma th $\sim$ al hqei $\sim$ in John 14:17 and 15:26. Just as Christ was the Truth (John 14:6) so the Paraclete-Spirit is the Truth and guides and leads people to the Truth and into the truth through the Scriptures.

Today there is an odd emphasis on experience among Christians. We might accept that faith is also experiential. But, although faith is experiential it should also be recognised that according to the Johannine perspective the Paraclete-Spirit will never lead a believer into an "experience" that is contrary to the Word of God (John 16:1314). This implies that according to John a spiritual experience is only valid insofar as it is in line with the Word of God. It seems to me that in Johannine thought the Paraclete-Spirit would lead or guide believers into an experience of Jesus, his truth, his message and his ministry. This experience, to know and to understand Jesus, would change the lives of people. ${ }^{17}$ False spirits will bring false teaching, but John argues that once we hear what they have to say about Jesus, we can judge whether what they proclaim is true or false. We could go so far as to say that there is a real danger of people proclaiming that they received a message from the Holy Spirit or, as they state from God, but since their proclamation does not agree with the Biblical revelation, concerning the revelatory work of the Paraclete-Spirit, it should be seen as false teaching. Johannine pneumatology enables us to address this danger with its focus on the fact of the Paraclete-Spirit's focus on Jesus in his ministry.

\subsection{The Paraclete-Spirit as aid to believers}

In John 14:16 Jesus promised the disciples a[I on parakl ht on. In Johannine thought, the Paraclete-Spirit is "another of the same kind" as Christ, an Adviser who is called alongside to enable the believer to carry on in times of want and need. It seems to me that the Paraclete-Spirit as the believer's a [ I on parakl ht on accentuates his deity since his work is similar to that of Christ in his role as paraklhtor. 
As explained, it seems apparent that the Johannine description of the works of the Paraclete-Spirit point toward his deity - his oneness within the Godhead, together with the Father and the Son. ${ }^{18}$

\subsection{The Paraclete-Spirit is given and sent by both the Father and the Son}

This is a difficult and contentious topic to discuss. It is not only difficult and contentious because of the debate and division that continues since at least CE 381 to the present-day, it is also difficult and contentious because of the fact that much is debated but little is exegeted. It seems more often than not that systematic theologians have tried to force texts to say what they want them to say. In our discussion here we need to keep in mind that the concept of Trinity is a dogmatic one and not an exegetical one. We also need to acknowledge that when we talk about procession we immediately are on the terrain of systematic theology, for the relationship of the Paraclete-Spirit to the other members of the Trinity is expressed in systematic theology by the term procession, indicating the Holy Spirit came forth from both the Father and the Son. The Constantinople Creed affirmed this doctrine in CE 381. At Constantinople the Nicene Creed was amended in an attempt to address the heresy of the pneumatomachi who denied the deity of the Holy Spirit. To the Nicene: "We believe in the Holy Spirit" was added "The Lord and Giver of Life". This addition was to make it abundantly clear that the church (East and West) believed that the Holy Spirit is God, like the Father and the Son.

\section{Conclusion}

The Paraclete-Spirit in the Johannine Gospel works to glorify Jesus, as the Son of the Father. We noted that the role of Jesus is to make the Father known. The Spirit and the Son as a result operate together so that the world may know the Father, and in knowing Him, may become his children. Omnipresence, inwardness, and permanence as three marks and new phases of the activity of Jesus are, as a result of the ever-present Paraclete-Spirit, rendered possible. All of these were either excluded by the conditions of Jesus' earthly life or could only manifest themselves imperfectly. But present. 
once the Paraclete-Spirit has come this will change. The Johannine Gospel culminates theologically in the glorious notion of God Himself, eternally present in the believer, through the Paraclete-Spirit who unites us with Jesus as Jesus is united with the Father.

Through the sending of Jesus the Paraclete-Spirit becomes active in the lives of his disciples. And through the coming of Jesus the Paraclete-Spirit is present with his disciples. Because of the presence of the Paraclete-Spirit Jesus' followers become partakers in his life and work through faith in Him that the Paraclete-Spirit empowers them to have. The Paraclete-Spirit takes possession of the followers of Jesus as the bringer of a new life, and supports them in their struggle with the flesh and the sin. Through the ever-present Paraclete-Spirit that gradually subdues mankind to Jesus as the Christ of God and to the rule of Christ, the natural life becomes "spiritual" life. The Johannine portrayal of the Paraclete-Spirit gives us a better (fuller) understanding of the identity, role and function of the Holy Spirit. For this reason it should be seen as mandatory for Christians to take the Johannine perspective into account when they contemplate over and reflect on the doctrine of the Holy Spirit.

\section{List of references}

AUNE, D.E. 1972. The cultic setting of realised eschatology in Early Christianity. Leiden: Brill.

BEASLEY-MURRAY, G.R. 1999. John. Nashville: Nelson.

BROWN, R.E. 1982. The gospel according to John. Vol. 1. London: Chapman.

BROWN, R.E. 1984. The gospel according to John. Vol. 2. London: Chapman.

BURGE, G.M. 2000. John. Grand Rapids: Zondervan.

CASURELLA, A. 1983. The Johannine Paraclete in the church fathers: a study in the history of exegesis. Tübingen: Mohr.

DE LA POTTERIE, I. 1976. The Paraclete. Bible bhasyam, 2:120-140.

DETTWILER, A. 1995. Die Gegenwart des Erhöhten: eine exegetiche Studie zu den johanneischen Abschiedsreden (Joh 13, 31-16, 33) unter besonderer Berücksichtigung ihres Relecture-Charakters. Göttingen: Vandenhoeck.

DIETZFELBINGER, C. 1985. Paraklet und theologischer Anspruch im Johannesevangelium. Zeitschrift für Theologie und Kirche, 82:389-408.

DIETZFELBINGER, C. 1997. Der Abschied des Kommenden. Tübingen: Mohr.

DUNN, J.D.G. 1975. Jesus and the Spirit: a study of the religious and charismatic experience of Jesus and the first Christians as reflected in the New Testament. Philadelphia: Westminster.

JOHNSON, A.L. 1988. Faith misguided: exposing the dangers of mysticism. Chicago: Moody.

JOHNSTON, G. 1970. The Spirit-Paraclete in the gospel of John. Cambridge: Cambridge University Press. (Studiorum Novi Testamenti Societas Monograph Series, 12.) 
JOUBERT, J.V. 1997. God van die kruis of God van die filosowe? 'n Dogmatologiese en godsdiensfilosofiese analise van die Godsidee in die denke van Jürgen Moltmann. Pretoria: Universiteit van Pretoria. (Ongepubliseerde D.D.-proefskrif.)

JOUBERT, J.V. 2005. 'n Vergelykende studie van die Parakleet uitsprake in die Evangelie volgens Johannes en die Heilige Gees in die Briewe van Johannes. Pretoria: Universiteit van Pretoria. (Ongepubliseerde D.D.-proefskrif.)

KEENER, C.S. 2003. The gospel of John: a commentary. 2 Vols. Peabody: Hendrickson.

KÖSTENBERGER, A.J. 2004. John. Grand Rapids: Baker.

MOLONEY, F.J. 1998a. Glory not dishonor. Minneapolis: Fortress.

MOLONEY, F.J. 1998b. The gospel of John. Minnesota: Liturgical Press.

PARSENIOS, G.L. 2005. Departure and consolation: the Johannine farewell discourses in light of Greco-Roman literature. Leiden: Brill.

SCHNACKENBURG, R. 1982. The gospel according to John. Vol. 3. London: Burns \& Oates.

SEGOVIA, F.F. 1991. The farewell to the word: the Johannine call to abide. Minneapolis: Fortress.

TOLMIE, D.F. 1995. Jesus' farewell to the disciples: John 13:1-17:26 in narratological perspective. Leiden: Brill. (Biblical Interpretation Series, 12.)

WINDISCH, H. 1968. The Spirit-Paraclete in the fourth gospel. Philadelphia: Fortress. (Facet Books Biblical Series, 20.)

\section{Key concepts:}

Holy Spirit

Johannine theology

paracleet

Kernbegrippe:

Heilige Gees

Johannese teologie

parakleet 
